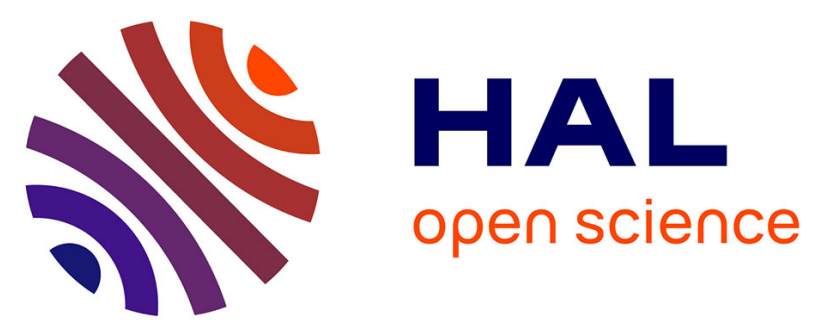

\title{
Radioactivity recorded by clay minerals in the Shea Creek area, Athabasca Basin (Canada): Implications for uranium transfers and exploration
}

Thierry Allard, Daniel Beaufort, Maximilien Mathian, Freddy Uri, Elisa Brun, David Quirt

\section{- To cite this version:}

Thierry Allard, Daniel Beaufort, Maximilien Mathian, Freddy Uri, Elisa Brun, et al.. Radioactivity recorded by clay minerals in the Shea Creek area, Athabasca Basin (Canada): Implications for uranium transfers and exploration. Journal of Geochemical Exploration, 2018, 188, pp.340-349. 10.1016/j.gexplo.2018.02.003 . hal-01724111

\section{HAL Id: hal-01724111 \\ https://hal.sorbonne-universite.fr/hal-01724111}

Submitted on 6 Mar 2018

HAL is a multi-disciplinary open access archive for the deposit and dissemination of scientific research documents, whether they are published or not. The documents may come from teaching and research institutions in France or abroad, or from public or private research centers.
L'archive ouverte pluridisciplinaire HAL, est destinée au dépôt et à la diffusion de documents scientifiques de niveau recherche, publiés ou non, émanant des établissements d'enseignement et de recherche français ou étrangers, des laboratoires publics ou privés. 


\title{
Radioactivity recorded by clay minerals in the Shea Creek area, Athabasca Basin (Canada): Implications for uranium transfers and exploration
}

\author{
Thierry Allard $^{\mathrm{a}, *}$, Daniel Beaufort ${ }^{\mathrm{b}}$, Maximilien Mathian ${ }^{\mathrm{a}}$, Freddy Uri ${ }^{\mathrm{b}}$, Elisa Brun ${ }^{\mathrm{b}}$, David Quirt ${ }^{\mathrm{c}}$ \\ a IMPMC, CNRS-UMR 7590, Université Pierre et Marie Curie, IRD, MNHN, T 23-24, 5ème étage, 4 Place Jussieu, 75252 Paris, France \\ b IC2MP, CNRS-UMR 7285, Université de Poitiers, Bâtiment B35, 6 Rue Michel Brunet, TSA 51106, 86073 Poitiers Cedex 9, France \\ ${ }^{\mathrm{c}}$ AREVA Resources Canada Inc., 810 45th Street West, Saskatoon, Saskatchewan S7K 3X5, Canada
}

\section{A R T I C L E I N F O}

\section{Keywords:}

Uranium

Ore genesis

Unconformity

Clay minerals

Radiation-induced defects

Radioelement migration

\begin{abstract}
A B S T R A C T
The understanding of uranium mobility in the geosphere is a prerequisite for the modelling of high-level nuclear waste repositories and economic uranium deposit genesis. To complement more classical geochemical and mineralogical approaches, this understanding can be improved by measuring the record of past cumulative radioactivity as stable radiation-induced defects in clay mineral structure. This study focuses on world-class unconformity-related uranium deposits of the Athabasca Basin (Canada) for which the source, timing, and paths of the uranium-bearing fluids are still matters of debate. A set of 46 samples collected from the Athabasca Group sandstones in the Shea Creek area of the western Athabasca Basin, up to $634 \mathrm{~m}$ above either the unconformity (barren drill hole) or uranium mineralization, was selected in order to locate the paleo-occurrences of radioelements. A relevant three-dimensional view is shown by plotting (i) the concentrations of radiation-induced defects (RID's) in clay minerals, (ii) the present dose rate, and (iii) the distance to the mineralization or unconformity. The results clearly reveal different cases, such as geochemical background, equilibrated dose rate, late accumulations of radioelements, and/or records of their past temporary occurrence. Noticeable paleo-occurrences, now leached away, are revealed within $100 \mathrm{~m}$ of the structures hosting present-day mineralized bodies, which is in line with a recent model of long range lateral paleofluid flow in a basinal permeable formation, and may be useful for exploration, albeit within a proximal range. Such results rely on the detection of RID's in clay minerals, as chemical analysis or gamma counting alone detect only the present concentration of radioelements and are unable to distinguish between accumulations, equilibration of transfers, or temporary occurrences of uranium. This study represents a first step toward spatial 3D quantitative reconstruction of $U$ transfers, which will require time constraints and artificial dosimetry to improve models of genesis of high-grade unconformity-related deposits and to identify paleo-pathways of U migration.
\end{abstract}

\section{Introduction}

The understanding of uranium mobility in the geosphere is a prerequisite for the prediction of its dissemination in the environment or the safety assessment of high-level nuclear waste repositories (HLNWR), for which there are increasingly detailed studies of corresponding biogeochemical mechanisms at the molecular scale (e.g. Maher et al., 2013; Merroun and Selenska-Pobell, 2008; Christensen et al., 2004). Its complete understanding is also a major key for the discovery of new world-class high-grade uranium ore deposits and for the modelling of their metallogenesis. Among these, the Athabasca Basin (Canada) hosts numerous unconformity-related uranium deposits (URUD) (Kyser and Cuney, 2009; Jefferson et al., 2007; Jefferson and Delaney, 2007). A metallogenetic model for the deposition of the URUD has been proposed and improved (Hoeve and Sibbald, 1978; Hoeve et al., 1980; Hoeve and Quirt, 1984; Wallis et al., 1985; Fayek and Kyser, 1997; Kyser et al., 2000), but the source, timing, and pathways of the uranium-bearing fluids, although increasingly documented, are still matter of debate. This main metallogenetic model for the URUD implies large-scale inputs of uranium from at least hundreds of meters away from the mineralization at the unconformity (Dahlkamp, 1993; Kyser and Cuney, 2009; Richard et al., 2016). Fluid inclusions in quartz gave direct evidence of high concentration of uranium, up to $\sim 600 \mathrm{ppm}$ (Richard et al., 2010, 2012, 2016). The possible migration of uranium at the scale of the basin is suggested by models of paleofluid flow, such as the hydrostratigraphic model by Hiatt and Kyser (2007), the numerical convective model by Cui et al. (2012) or the numerical fluid pressure model by Chi et al. (2013).

\footnotetext{
* Corresponding author.

E-mail address: thierry.allard@impmc.upmc.fr (T. Allard).
} 


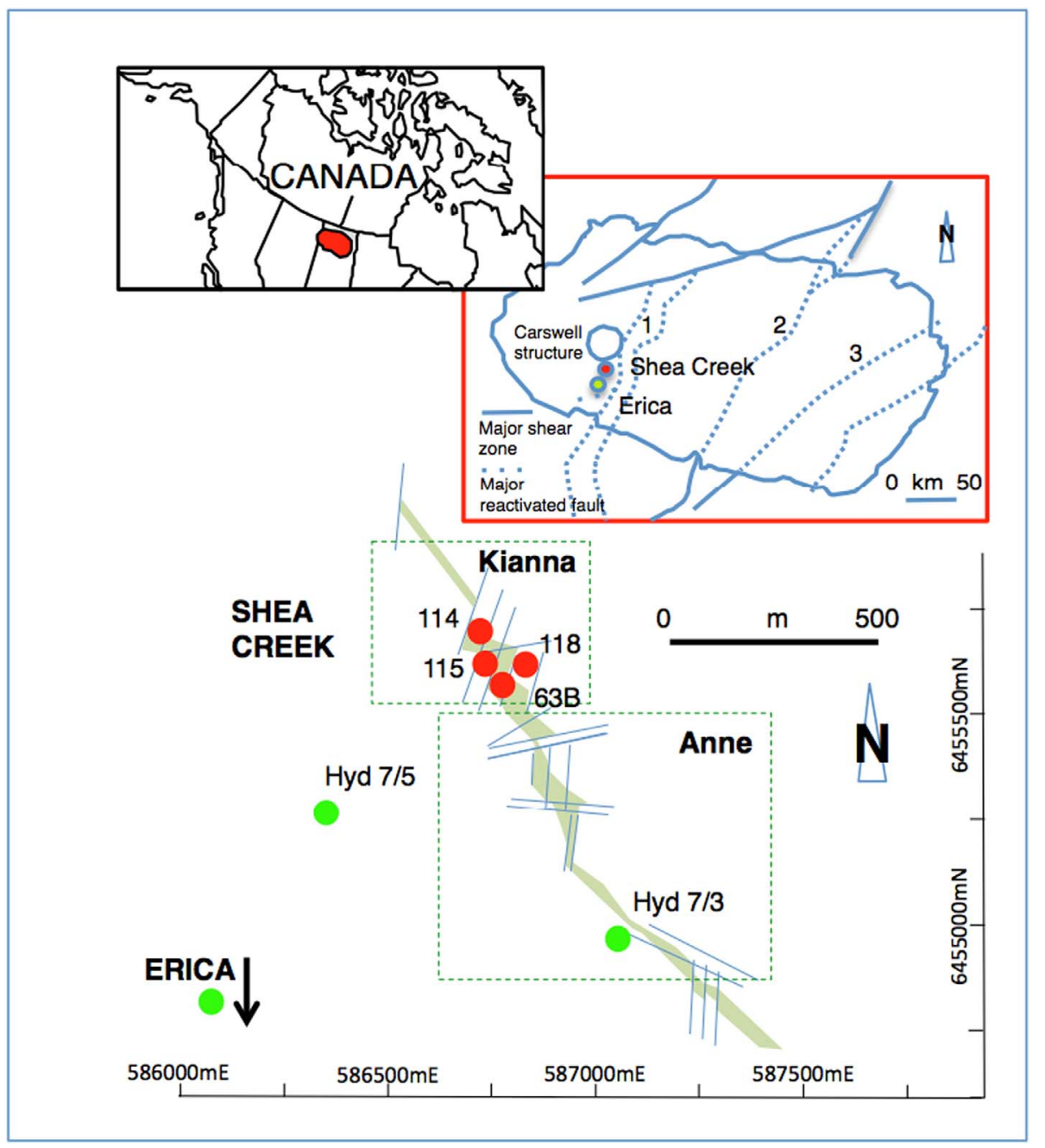

Fig. 1. Location of the Athabasca Basin (red in top left insert) northern Saskatchewan and Alberta, Canada. In the Athabasca Basin (back insert), the Shea Creek and the Erica areas are some tens kilometers south of the Carlswell structure. The reactivated faults are named: 1 : Clearwater zone; 2: Snowbird tectonic zone; 3: Cable Bay shear zone. The detail of the Shea Creek map represents the location of drill holes, faults as lines, and pelite gneiss lithology as green shading. Drill holes in red are mineralized and those in green are barren. "Hyd" refers to the Shea Creek drill holes that were made specifically for hydrological sampling and monitoring. The Erica area is located at around $10 \mathrm{~km}$ southwest of the Shea Creek area. (For interpretation of the references to colour in this figure legend, the reader is referred to the web version of this article.)

To improve the knowledge of the uranium migration processes, several studies, besides geochemical investigations, have considered the mineralogy, size fraction, and morphology of clay minerals as pathfinders (see, e.g., Hoeve and Quirt, 1984; Laverret et al., 2006; Kister et al., 2006). In order to reveal radioelement transfers, one can also take advantage of the record of the ambient cumulative dose of radioactivity by radiation-induced defects (RIDs) in quartz (Chatagnon, 1986; Botis et al., 2006; Hu et al., 2008; Cerin et al., 2017) or clay minerals (Clozel et al., 1994; Morichon et al., 2008, 2010a, 2010b; Allard et al., 2012; Riegler et al., 2016) as evidenced by electron paramagnetic resonance spectroscopy (EPR). In the Athabasca Basin, temporary past radioactivity was revealed by the analysis of RID's in quartz and clay minerals up to $400 \mathrm{~m}$ and $1000 \mathrm{~m}$ away from the mineralization levels, respectively. The finding of one significant paleo-occurrence of radioelements at around $1000 \mathrm{~m}$ and one at $500 \mathrm{~m}$ vertical distances from unconformity by the study of clay minerals (Morichon et al., 2010b) may have important consequence on specifying the genetic model of ore deposits in the Athabasca Basin and this should be verified on other sites. Moreover, scattered data of [RID's] versus dose rate, instead of a single dosimetry curve, indicated anomalies related to past accumulations or losses of radioelements recorded since the formation of the clay minerals (Allard and Muller, 1998; Morichon et al., 2010b). As a matter of fact, previous studies have shown that the concentration of RID's is a function of cumulative dose (Allard et al., 2012). For the same dose rate in a natural system, the concentration will depend on time. Hence, with this methodology, time of formation of clay minerals must be constrained to reveal past transfers of radioelements using the RID's concentration.

The radioactivity at the origin of RID's dominantly arises from ${ }^{238} \mathrm{U}$, ${ }^{235} \mathrm{U}$, and ${ }^{232} \mathrm{Th}$ decay chains (including daughters), and ${ }^{40} \mathrm{~K}$. Nevertheless, uranium is particularly important, owing to its relative abundance and mobility in oxidized environments and the relative immobility of Th, as previously shown for the Nopal U-deposit, Mexico (Allard and Muller, 1998) or the Coutras deposit, France (Allard et al., 2007). This study focuses on the Shea Creek area of the Athabasca Basin that represents a good example of the Athabasca unconformity-related U-deposits (Sheahan et al., 2016), and in which the clay minerals (i.e. kaolinite, dickite, illite, and sudoite) predated or were contemporaneous with the formation of the uranium deposits (Hoeve and Quirt, 1984; Jefferson et al., 2007). In addition, a lot of geochemical and mineralogical data were available for this part of the Basin. Their paragenetic setting means that there is a good rationale for the use of RID's in clays as a proxy for past radioactivity. The Erica area, adjacent to the Shea Creek area, is also considered because it has similar geology, but to date is barren. Thus it represents the unmineralized and relatively unaltered regional background in the surrounding of Shea Creek (Laverret et al., 2006). Despite the evidence of past occurrence of uranium in several locations in the Athabasca Basin from the presence of RID's in quartz and clay minerals, these findings represent preliminary data that do not yet frame a clear picture of radioelement circulation throughout rock hosting deposit because the distance of the samples with respect to mineralized bodies and the present-day radioactivity have to be also jointly considered. Thus, in order to reveal paleo-occurrences of radioelements at long distance in the Shea Creek 
and Erica areas, 46 samples of Athabasca sandstone containing clay minerals that have been well identified by previous studies (Quirt, 2001; Kister et al., 2006; Laverret et al., 2006, 2010; Uri, 2012) were selected and three-dimensional views of cumulative radioactivity in sandstones were built by plotting (i) the concentration of radiationinduced defects in clay minerals, (ii) the present dose rate, and (iii) the vertical distance to the mineralization or unconformity. Only radioactivity present after clay mineral formation was recorded by the RID's. The objectives were then twofold. The first one was to strengthen the approach of reading the record of past cumulative radioactivity using RID's in clay minerals because it is still an unusual methodology providing new relevant data. The second was to search confirmation of past transfers of radioelements at a long vertical distance (i.e. hundreds of meters) from the present-day uranium deposits, as found by Morichon et al. (2010b) from the study of various other deposits of the Athabasca Basin.

\section{Geological background}

The Athabasca Basin (Fig. 1) is a Paleo- to Mesoproterozoic intracratonic basin (Saskatchewan, Alberta, Canada) containing the Athabasca Group of quartz-rich arenitic sandstones (Ramaekers et al., 2007) that unconformably overly an Archean to Paleoproterozoic crystalline basement consisting mostly of metamorphic gneisses and granitoids (e.g. Annesley et al., 2005 and reference therein). Originally believed to have been circa $5 \mathrm{~km}$ thick (Pagel et al., 1980), the depth of the sandstone cover is presently about $1500 \mathrm{~m}$ in the central part of the Athabasca Basin. The deposition of the Athabasca sediments had progressively taken place between circa 1700-1500 Ma (Cumming and Krstic, 1992; Rainbird et al., 2007; Ramaekers et al., 2007; Jeanneret et al., 2016).

Concerning the following period, isotopic, microthermometric, petrological, and geochemical studies suggested that mineralization was the result of the mixture of oxidizing diagenetic sandstone brine with reduced basement-derived brine ascending along the fault zones (Hoeve and Sibbald, 1978; Wilson and Kyser, 1987; Hoeve and Quirt, 1984; Kotzer and Kyser, 1995; Kyser et al., 2000). The corresponding diagenetic-hydrothermal genetic model involves diagenetic high temperature (up to $200^{\circ} \mathrm{C}$ ) lateral fluid flow over hundreds of kilometers, which was suggested as soon as in the early studies of fluid inclusions (Pagel, 1975). The composition of brines together with the high related $\mathrm{U}$ concentration (up to about $600 \mathrm{ppm}$ ) were constrained from the study of fluid inclusions in quartz (Derome et al., 2005; Richard et al., 2010, 2011, 2012, 2016). Besides, detailed mineralogical and isotopic data showed that several episodes of $\mathrm{U}$ ore formation occurred around $1500 \mathrm{Ma}, 959 \mathrm{Ma}, 300 \mathrm{Ma}$ (Fayek and Kyser, 1997; Kotzer and Kyser, 1995; Kyser et al., 2000). In the Kianna deposit, one of the U deposits in the Shea Creek area, Sheahan et al. (2016) proposed a genetic model with formation of basement mineralization at about $1500 \mathrm{Ma}$, remobilization of this mineralization at around $1280 \mathrm{Ma}$ and $1100 \mathrm{Ma}$, and uraninite mineralization in the sandstone at $\sim 750$ and $\sim 500 \mathrm{Ma}$.

Nevertheless, the corresponding mechanism for large scale lateral circulation of mineralizing fluids, that were most pronounced in the permeable, coarse-grained basal units including conglomerates (Fair Point and Manitou Fall Formations), remains controversial. Thermally driven basin-scale convection (Hoeve and Sibbald, 1978; Wilson and Kyser, 1987; Raffensperger and Garven, 1995) was considered as unlikely by several authors (Kotzer and Kyser, 1995; Hiatt and Kyser, 2007) who claimed that fluids associated with uranium mineralization moved preferentially along the basal unconformity in the Manitou Fall Formation and not vertically over the Basin thickness. As a matter of fact, the hydrostratigraphic model for the eastern Athabasca Basin proposed by Hiatt and Kyser (2007), supported by the study of U isotopes by Holk et al. (2003), suggests long range west to east flow of mineralizing fluids with a vertical distance limited to a few hundreds of meters and focused by aquitards occurring above the aquifer in the sandstone formation. More specifically, Holk et al. (2003) showed anomalies of $\mathrm{U}$ some tens of meters around the unconformity at Cigar Lake and Mc Arthur River, and the quartz samples selected for fluid inclusion analyses by Richard et al. (2016) showing high U-content in the Shea Creek sandstone were located up to $30 \mathrm{~m}$ above the unconformity.

According to the diagenetic-hydrothermal model, the genesis of unconformity-related $\mathrm{U}$ deposits in the Athabasca Basin took place during a tectonically-active period at the beginning of the Mesoproterozoic (Hoeve and Sibbald, 1978; Hoeve and Quirt, 1984, 1987; Fayek and Kyser, 1997). Clay and uranium mineral parageneses formed in several steps: (i) Kaolinite to dickite transformation and kaolin to illite alteration during the deep burial diagenesis of sandstones ( $\mathrm{T} \sim 200^{\circ} \mathrm{C}$ and burial depth $\sim 5-6 \mathrm{~km}$; Hoeve and Quirt, 1984) and large-scale migration of uranium transported by acidic and oxidizing diagenetic solutions (Fayek and Kyser, 1997). Infiltration of diagenetic brine into the underlying basement rocks and then recycling into the sandstone cover as reducing saline fluids which resulted from the alteration of basement rocks; (ii) crystallization of illite and chlorite (sudoite and $\mathrm{Mg}$-Fe-chlorite) around the unconformity as part of the alteration process associated with structurally-related fluid-mixing systems (Hoeve and Sibbald, 1978; Pacquet and Weber, 1993; Laverret et al., 2006); (iii) massive deposition of uraninite at redox fronts near the unconformity (Hoeve and Quirt, 1987; Billault et al., 2002; Beaufort et al., 2005; Laverret et al., 2006; Kister et al., 2006; Alexandre et al., 2008).

The Shea Creek project is a joint-venture project of AREVA Resources Canada Inc. (ARC) and UEX Corporation located in the western portion of the Athabasca Basin, close to the Carswell structure (Fig. 1). In this area, the thickness of the Athabasca Group sandstone is 700 to $800 \mathrm{~m}$. The Shea Creek area was selected for the present study because it is a good example of the Athabasca unconformity-related uranium deposits with pods hosted in the basement and the sandstone (Sheahan et al., 2016). In addition, this choice was motivated by access to samples by AREVA and the excellent knowledge of this deposit area from numerous studies (e.g. Kister et al., 2006; Laverret et al., 2006, 2010; Sheahan et al., 2016). The nearby Erica area was also selected because it is close to Shea Creek (about $10 \mathrm{~km}$ ) and has a similar local geology. The Erica 1 drill hole did not intersect a mineralized structure in the basement nor any significant hydrothermal alteration on either side of the unconformity and thus the rocks have been considered representative of the unmineralized regional background in the vicinity of Shea Creek (Laverret et al., 2006; Kister et al., 2006).

Thus, the Erica area contains barren drill holes, while Shea Creek holes (except the 'Hyd' drill holes) intersect $\mathrm{U}$ mineralization (Fig. 1). Host-rock hydrothermal alteration led to the neoformation, and replacement of the Al-bearing minerals in both Athabasca Group sandstones and underlying metamorphic basement rocks by clay minerals, including illite and sudoite. The nature, spatial distribution, and timing of formation of basin-hosted and basement-hosted clay minerals in this area have been studied by Quirt (2001), Laverret et al. (2006, 2010), Kister et al. (2006), Uri (2012), and Sheahan et al. (2016). In the Shea Creek area, three episodes of hydrothermal formation of illite were recognized at $1453 \pm 2,1330 \pm 20$, and about $1235 \mathrm{Ma}$ by K-Ar dating (Laverret et al., 2010). This age distribution is not significant and should not substantially impact the concentration of RID's. Older occurrences of $1.675 \mathrm{Ga}$ "pre-ore" illite and chlorite were also proposed by Alexandre et al. (2009), but have not been identified in this studied area.

Moreover, a feature of the Shea Creek area is the presence of local unaltered sandstone compartments that have been preserved from the later diagenetic alteration and hydrothermal alteration, in which earlier diagenetic kaolinite and dickite still persist (Uri, 2012). This kaolinite is diagenetic in origin, as also observed in the eastern portion of the Athabasca Basin, but is not resulting from the meteoric water alteration as for the late $(<300 \mathrm{Ma})$ kaolinite originating from meteoric water 
alteration (Wilson and Kyser, 1987; Mercadier et al., 2011). These meteoric kaolinites are not present in the sandstone of the studied area. Indeed, diagenetic (or detrital) origin of the minerals investigated in this study (including dickite) has been verified by the petrographic study of thin sections (Quirt, 2001; Laverret et al., 2006; Uri, 2012). Thus, kaolin minerals occur as pore-filling aggregates in which only local alteration and replacement by illite is usually observed. The intensity of the illitisation process of kaolinite is particularly weak near the base of the sandstone column, but it can be observed unambiguously at local scale in all samples. None of the basement samples from Shea Creek contain kaolinite. Moreover, the diagenetic origin of the kaolinite having the highest RID's concentration (Shea Creek 114-11 (677.80), 114-11 (701.45) and 114-11 (707.10)) has been verified from stable isotope analysis (Uri, 2012). $\delta^{18} \mathrm{O}$ and $\delta \mathrm{D}$ of these kaolinite specimens (and the fluid in isotopic equilibrium at $200{ }^{\circ} \mathrm{C}$ ) are similar to those obtained at regional scale for the diagenetic kaolin minerals (Kotzer and Kyser, 1995). As kaolin minerals predate illite everywhere in the sandstone of Shea Creek (Quirt, 2001; Laverret et al., 2006), we can estimate their minimal age from the K-Ar dating performed on illite sampled in sandstones from several drill-hole nearby within the Shea Creek area (Laverret et al., 2010): kaolinites from the Shea Creek sandstone formed between 1.7 and $1.5 \mathrm{Ga}$. In addition, precipitation of sudoite was cogenetic with diagenetic-hydrothermal illite (Laverret et al., 2006; Kister et al., 2006). Consequently, in the Shea Creek area, the clay minerals predated or were contemporaneous with the deposition of the uranium orebodies.

\section{Materials and methods}

\subsection{Sampling}

This study relies on a set of 46 sandstones samples collected above the unconformity and/or $\mathrm{U}$ mineralization from various drill holes in the Shea Creek and Erica areas of the Athabasca Basin (Fig. 1; Table 1). Drill core samples (10 to $20 \mathrm{~cm}$ long) taken from exploration drill holes were selected on the basis of the drill logs prepared by the ARC exploration geologists, the petrographic study of thin sections, and the same parameters used by Morichon et al. (2010b) for their sample selection, i.e. sedimentary facies; measurable distance to known mineralization, major faults or brecciated zones; vertical distance to the subAthabasca unconformity in absence of mineralization or faulting. The clay mineral separates were recovered from tens to hundred grams of sandstone cores through the use of a freeze-thaw method (Liewig et al., 1987 ) that involves sample disaggregation without grinding. The claysize $(<2 \mu \mathrm{m})$ fraction was obtained by shaking the sample mechanically in water for $12 \mathrm{~h}$ and extracting the material using a Jouan GR4.22 centrifuge. The amount of clay required for EPR analysis was around $20 \mathrm{mg}$. The mineralogy of the size-fraction was determined using X-ray diffraction. The combination of the determination of clay species together with chemical analyses of raw samples (Table SI-1) provided the total content of clay minerals, using normative calculation (e.g., Quirt, 1995). The chemical compositions of the clays were determined by microprobe analysis of monominerallic samples. Corresponding clay mineral contents are reported in Table 1 for each group of clay minerals. This parameter was used to normalize the dose rate, as radioactive minerals are dominantly disseminated in the clay matrix, according to optical and scanning electron microscope observations of the thin sections of the samples.

The distance parameter reported in Table 1 and in the following text is a vertical distance of the sample either to the sandstone basement unconformity (barren drill hole) or to the edge surface of the closest mineralization intersected by the drill hole (mineralized drill hole). Here mineralization is considered to be rock bodies that provide > $300 \mathrm{cps}$ on a SPP $\gamma$ scintillometer, with the $300 \mathrm{cps}$ being approximately 200-300 ppm U. For instance, the distance in Erica 1 refers to the unconformity located at $796.5 \mathrm{~m}$ (barren drill hole), whereas for Shea
Creek 114 it is the distance to the first mineralization level at $678.5 \mathrm{~m}$ depth. Using this parameter, one objective of this study is to examine the record of past $U$ transfers at various distances from already known pathways such as the unconformity or mineralization, which is an obvious record of fluid flow.

\subsection{Chemical analyses}

Whole-rock analyses of major, minor, and trace elements were performed on homogeneous half-core samples using Inductively Coupled Plasma - Optical Emission Spectrometry (ICP-OES) and Inductively Coupled Plasma - Mass Spectrometry (ICP-MS) analyses at the SARM, CRPG-CNRS, Nancy, France (see http://www.crpg.cnrsnancy.fr/SARM/index.html for further information including the analytical errors). Major and minor concentrations are reported in Table SI1. The $\mathrm{Si}, \mathrm{Al}, \mathrm{Fe}, \mathrm{K}$ concentrations were used in normative calculation of clay mineral content. The $\mathrm{U}$, Th, and $\mathrm{K}$ concentrations were used in our study to calculate the present dose rates, as detailed in Results and discussion section.

\subsection{Electron paramagnetic resonance}

Electron Paramagnetic Resonance spectroscopy (EPR) is a very sensitive (down to the atomic ppm), selective, and non-destructive method devoted to examination of paramagnetic species, i.e. those having unpaired electron(s), such as ions of transition elements (like $\mathrm{Fe}^{3+}, \mathrm{V}^{4+}, \mathrm{Mn}^{2+}, \mathrm{Cr}^{3+}$ ), organic-free radicals, or radiation-induced defects (RID's) in minerals (Calas, 1988). It is based upon the absorption of a quantum of microwave energy favored by the splitting of specific spin energy levels under a magnetic field. The measurements were performed at $9.89 \mathrm{GHz}$ (X-band) on a Bruker EMXplus ${ }^{\mathrm{TM}}$ spectrometer at room temperature on air-dried powders. The measurement parameters were a $100 \mathrm{kHz}$ modulation frequency, a $40 \mathrm{~mW}$ microwave power, and a modulation amplitude of $0.3-0.5 \mathrm{mT}$.

All spectra were normalized as a function of mass, recording gain, and a constant filling factor of the resonant cavity. The paramagnetic species, such as RID's, can be characterized by a "g" effective factor that is derived from the resonance condition of EPR and that locates the transitions on the magnetic field axis (Calas, 1988).

On the X-band $(9.89 \mathrm{GHz})$, the RID's spectra are described by apparent axial symmetry and two main components, i.e. $g_{\text {parallel }}\left(g_{/ /}\right)$and $\mathrm{g}_{\text {perpendicular }}(\mathrm{g} \perp)$. The $\mathrm{g} \perp$ value was measured at the minimum of the perpendicular component (see Fig. 2 and Clozel et al., 1994).

The concentration of RID's in the clay minerals was measured by double integration of the EPR signal and calibrated by reference to a BRUKER standard ("strong pitch $\mathrm{KCl}$ ") to provide the number of spins per gram of sample.

The background was approximated by a straight line and subtracted from the spectrum. The total error on the RID concentration is $\pm 15 \%$, taking into account weighing, sample height in the tube, sample position in the cavity, and systematic error from the EPR apparatus.

The implicit assumption of this methodology is that the production of RID's by ionizing radiations is quite similar for kaolinite, dickite, illite, and sudoite (Morichon et al., 2008, 2010a, 2010b). This assumption is supported by the four clay minerals being phyllosilicates, by the presence of the same nature of RID's (electron holes on oxygen ions of the structure), and also the same range of doses used for dosimetry (data not shown). This is not the case for other minerals like carbonates and phosphates that have different structures and RID's (Ikeya, 1993). In addition, we assume that alpha, beta and gamma rays effects are similar in clay minerals, as shown for kaolinite by Allard and Muller (1998). The three-dimensional plots were drawn using Origin $\bigodot$ software. 


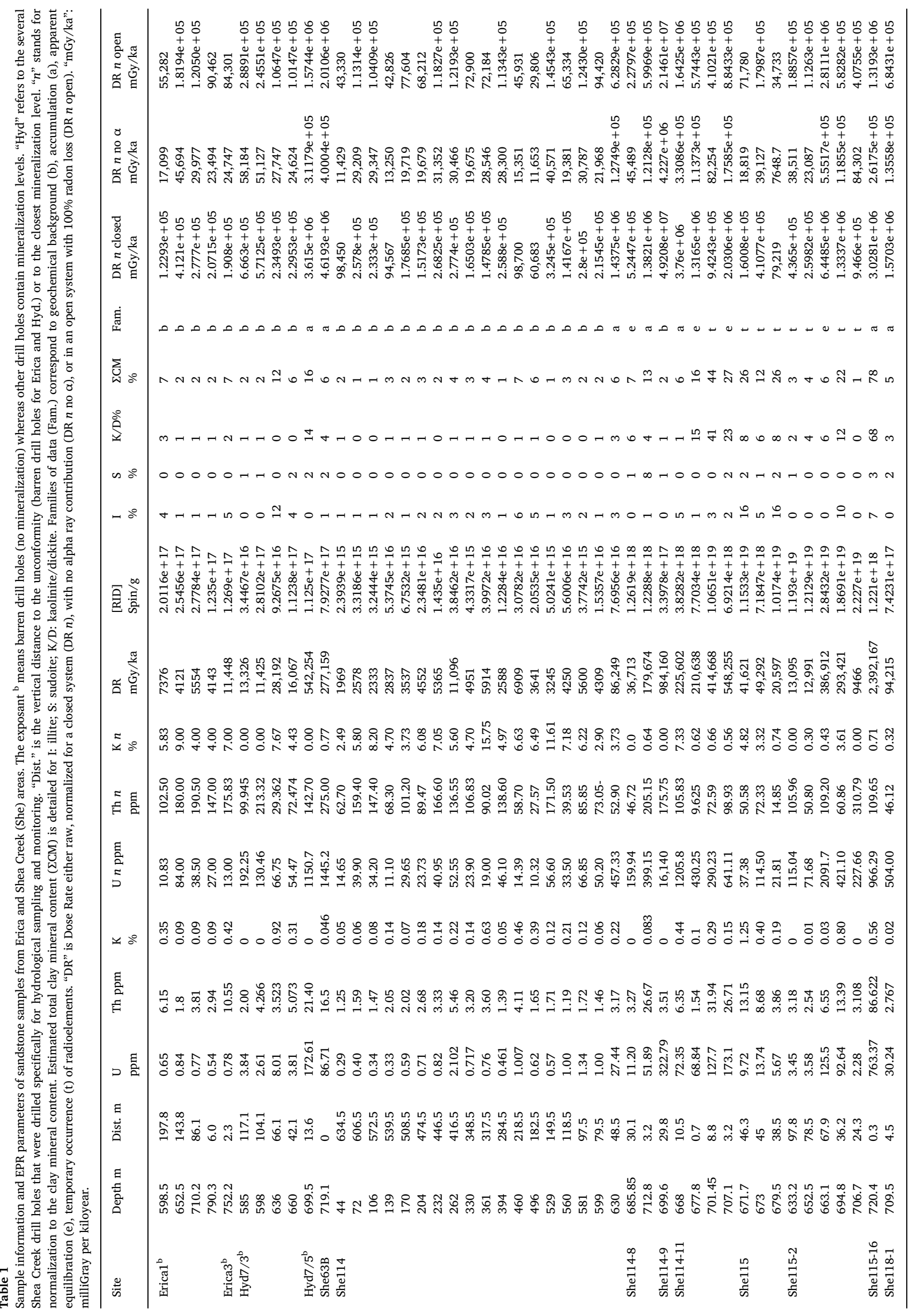




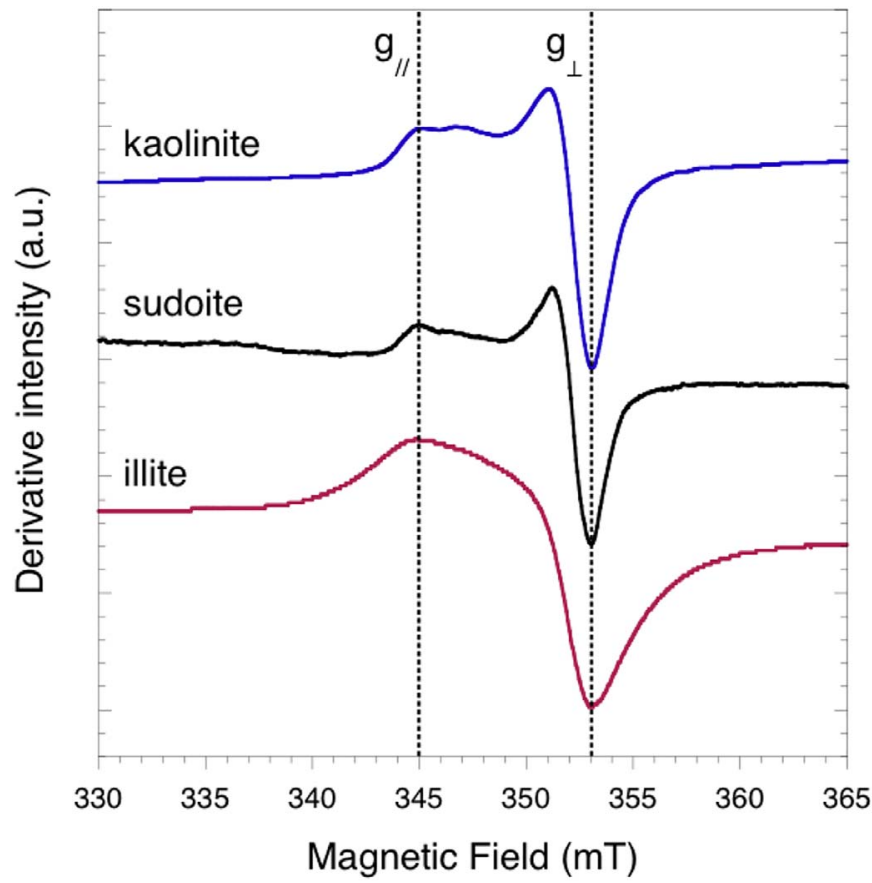

Fig. 2. EPR spectra of radiation-induced defects in clay minerals from the Athabasca Basin: dominant kaolinite (She115-2 (663.1)), dominant sudoite from the basement (Hyd7/5 (684)), pure illite (Hyd7/3 (636)). Hyperfrequency is $9.89 \mathrm{GHz}$. Intensity of spectra is in arbitrary units (a.u.). While the shape of the spectra may be slightly different, the main apparent components $\left(g_{/ /}\right.$and $\left.g \perp\right)$ are similar. They correspond to RID's stable at the scale of geological periods.

\section{Results and discussion}

\subsection{Dose rate}

The RID concentrations show no clear correlations with the U, Th or $\mathrm{K}$ concentrations (Supplementary Information Fig. SI-1), confirmation of the expectation that [RID] depends on the total cumulative dose and not on present day concentrations of radioelements. Considering the similar age for the studied clay minerals, the relevant parameter to visualize the radioactivity at the origin of RID's is then the dose rate. In this study, the dose rate was calculated by assuming a geochemically closed system, which is reasonable given the clogged porosity observed in thin sections by microscopy.

According to Aitken (1985), the elementary dose rates for the uranium and thorium decay chains are $3040 \mathrm{mGy} / \mathrm{ka}$ (milli gray per thousand years) and $819 \mathrm{mGy} / \mathrm{ka}$ for $1 \mathrm{ppm}$ of $\mathrm{U}$ and $\mathrm{Th}$, respectively, and $1071 \mathrm{mGy} / \mathrm{ka}$ for $1 \mathrm{wt} \%$ of $\mathrm{K}$. For instance, the raw dose rate of sample Hyd7/3 (585) (see Table 1) has been calculated as follows:

$(3.84 * 3040)+(2.0 * 819)+(0 * 1071)=13,312 \mathrm{mGy} / \mathrm{ka}$.

Subsequently, this raw dose rate was normalized to the clay content (see Sampling section) of the sample (in this case $2 \%$ ) giving an effective dose rate of $6.663 \mathrm{e}+05 \mathrm{mGy} / \mathrm{ka}$.

The resulting dose rates vary over 4 orders of magnitude $\left(6 \cdot 10^{4}-5 \cdot 10^{7} \mathrm{mGy} / \mathrm{ka}\right)$ for the sample set (Table 1$)$. The minimal error on dose rate calculated from analytical errors on concentrations of $U$, Th and $\mathrm{K}$ is about $30 \%$. The relations between the dose rate and concentrations of $\mathrm{U}$, Th, or $\mathrm{K}$ are reported in Fig. 3. All data are normalized to the clay content.

It is clearly observed that a strong correlation for dose rate exists only with the $\mathrm{U}$ concentration, which is explained by its relatively large elementary dose rate for the corresponding decay chain (see above). For Th and $\mathrm{K}$, no clear correlation is observed.

When considering the dose rate and distance to the mineralization only, it can be seen in Fig. 4 that values are distributed only along these
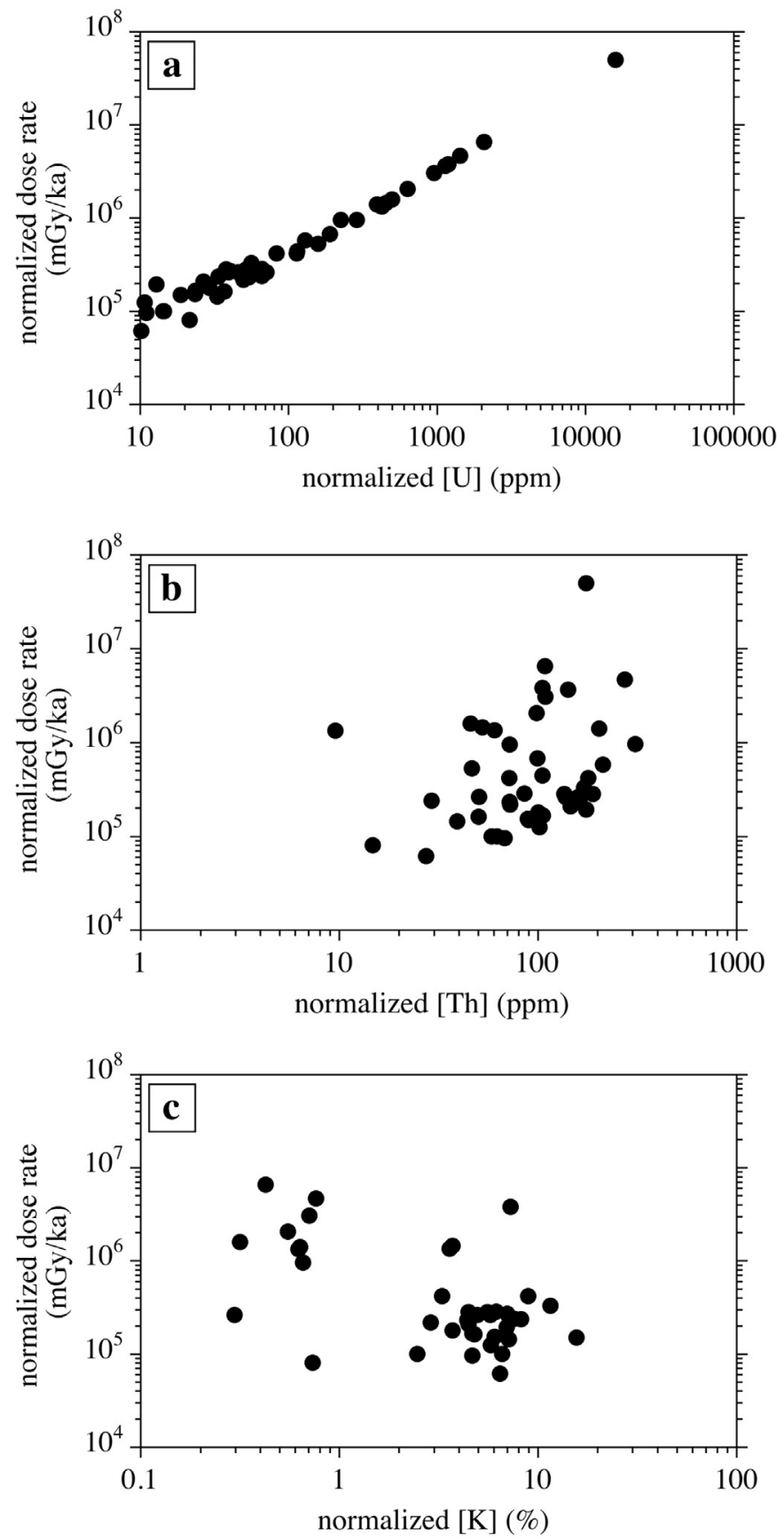

Fig. 3. Relation between present dose rate and [U], [Th], [K] (data normalized to the clay content.). The dose rate is dominantly controlled by the uranium concentration.

two corresponding axes. One extreme value on the dose rate axis has been excluded from the plot to show the detail of the relations for the rest of the data. This extreme sample is the richest in uranium $(\mathrm{U}=16,140 \mathrm{ppm})$. Samples along the distance axis have a very low dose rate and consequently are assigned to the geochemical background because they show similar values close to the mineralization and at large distances from mineralization. Samples with low distance and high dose rate are detailed below.

Aperture of the system can occur if the secular equilibrium of the $\mathrm{U}$ and th decay chain is disturbed by loss or accumulation of specific radioelements. To see this effect on the 3D plots, a worst case of $100 \%$ Radon loss is considered in Supplementary Information (Table 1; Fig. $\mathrm{SI}-2)$. Radon is an inert gas produced within the decay chains of ${ }^{238} \mathrm{U}$, ${ }^{235} \mathrm{U}$, and ${ }^{232} \mathrm{Th}$, that exhibits a strong mobility provided that the 


\section{a}

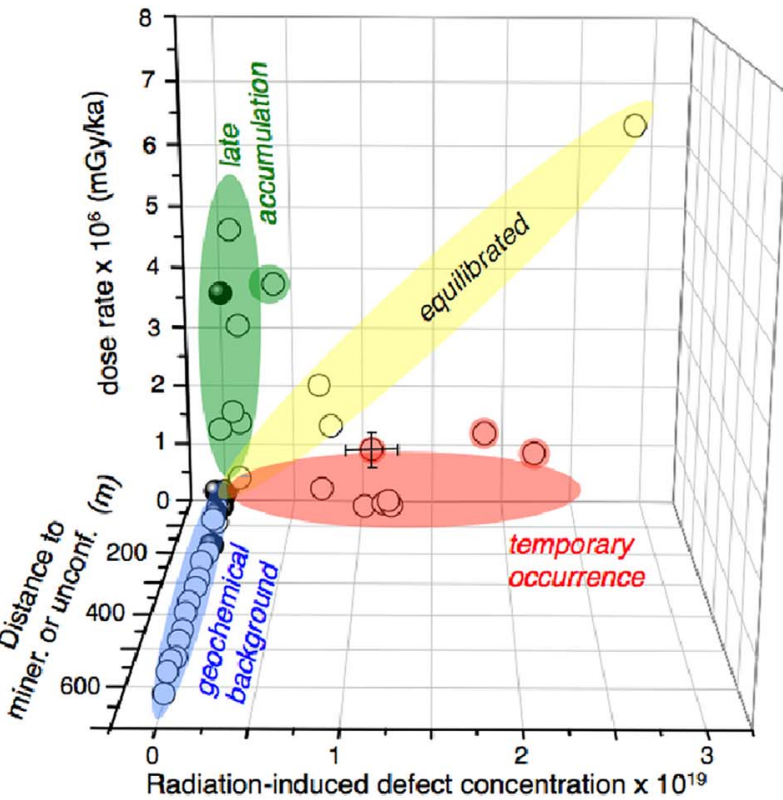

(spins/g)

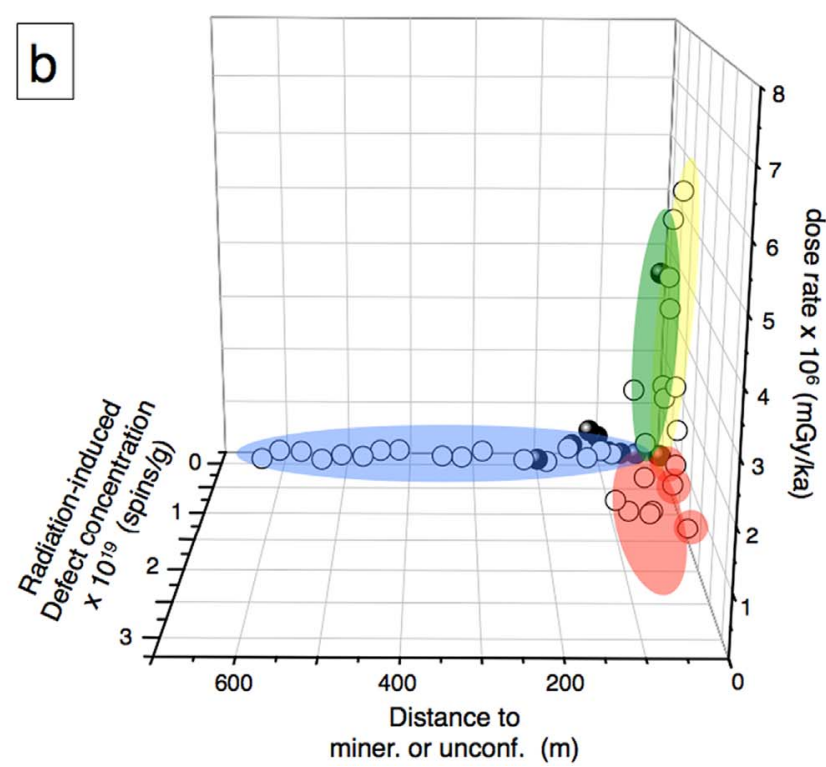

Fig. 4. 3D plots for clay-size fraction materials from sandstone samples, with two orientations. Dark points indicate barren drill holes, white circles refer to mineralized drill holes. The different areas correspond to geochemical background (blue area), equilibrated dose rate (yellow area), late accumulation (green area), and record of temporary occurrence (red area). This record provides clues for the reconstruction of radioelement paleo-occurrence within $100 \mathrm{~m}$ of the mineralization. Error bars are indicated in one central point. (For interpretation of the references to colour in this figure legend, the reader is referred to the web version of this article.)

porosity is open. This implies that lower elementary dose rates would be used to calculate the total dose rate (Aitken, 1985), resulting in lower values of this total dose rate. However, the general design of the plot remains unchanged, i.e. the same families of data are still revealed. The resulting interpretations are similar considering or not the aperture of the system.

Heterogeneous distribution of radioelements in the raw sample may also lead to a different effective dose rate, due to the small range of alpha particles in matter (circa $20 \mu \mathrm{m}$ in silicates; Ewing et al., 2003). This does not apply to ${ }^{40} \mathrm{~K}$, a beta emitter with circa $3 \mathrm{~mm}$ range, but only to the alpha emitters in the $U$ and Th decay chains. Indeed, when alpha emitters are hosted by distant and discrete grains, the alpha radiation only affects a thin rim around the grain surface and not the bulk of the collected clay fraction. The effective dose rate experienced by the clay is thus much lower. A calculation considering the extreme case of no contribution of alpha particles at all in $U$ and Th decay chains was performed, the result of which was a significant decrease of the dose rate but, again, no effect on the appearance of the diagram, because the similar families of data are still present (Table 1; Fig. SI-3).

Consequently, the data are plotted assuming a closed system and homogeneous distribution of $U$ and Th (Fig. 4).

\subsection{Concentration of RID's}

The EPR signals measured at high magnetic fields in the $g=2$ region are typical axial spectra that display different shapes but similar effective parallel and perpendicular components at $g_{/ /}=2.049$ and $\mathrm{g} \perp=2.002$, respectively (Fig. 2). These observations are consistent with the well-characterized A-, Ai-, and As-centers in kaolinite, illite, and sudoite, respectively, that are the most stable RID's (Clozel et al., 1994; Morichon et al., 2008; Riegler et al., 2016). Although related to different clay minerals, the three spectra exhibit broad axial components with similar $g$ values because they cannot be better resolved at the selected hyperfrequency (X-band), a feature that has been observed before for kaolinite (Clozel et al., 1994).

The concentrations of RID's in all samples sum the concentrations from kaolinite, illite, and sudoite, and range over 5 orders of magnitude $\left(2 \times 10^{15}-2.8 \times 10^{19}\right.$ spins per gram, Table 1$)$.

\subsection{Three-dimensional plots}

Representations of (i) the results as a function of the distance to the structures (either unconformity in barren sandstone or mineralization), (ii) the present normalized dose rate, and (iii) the concentration of RID's, are plotted in Fig. 4. Although U is present everywhere in various concentrations, the distance to the mineralized structure may be the most meaningful for mineral exploration. As can be seen from the two different views in Fig. 4a and b, the data are not randomly distributed in the whole space but are aligned parallel to the three axes and within the dose-rate/concentration plane. The interpretation of the data pattern suggests that four situations can be clearly distinguished: (i) the geochemical background defined above (see $\S 4.1$ ), that accordingly corresponds to very low concentrations of RID's and dose rates, irrespective of the distance to the mineralization (blue area within 0-650 m). The corresponding samples mostly correspond to dominant illite. This first group of samples is not thought to be limited by a saturation plateau of [RID] in illite (around $1 \times 10^{18} \mathrm{spins} / \mathrm{g}$ ) because illites with higher concentrations of RID's are also found in the set of samples (Table 1). This definition is relative to the other data, as inside the blue area, [RID] varies over three orders of magnitude (Table 1). (ii) a family of samples is located at short distance, with a variation of both dose rate and concentration of RID's (yellow area, Fig. 4a, b). This corresponds to a situation expected when no strong migration of $\mathrm{U}$ (accumulation or loss) is recorded. It is thus proposed that this family of samples corresponds to an equilibrated dose rate. Additional artificial dosimetry would be necessary to support this interpretation (Allard and Muller, 1998). (iii) the third set of samples corresponds to short distances, low concentrations of RID's, and strongly variable dose rate (green area). This is consistent with a late accumulation of radioelements. In this case, the dose rate experienced by the clay mineral was lower in the past and increased up to the present although with a negligible cumulative dose. Thus, the [RID] is consistent with the first (relatively long) event of exposure. The accumulation of radioelements after an early occurrence in the history of the system is in line with the different ages of uraninites that vary within 1500 to 300 Ma (e.g. Fayek and Kyser, 1997; Sheahan et al., 2016); (iv) the fourth group of samples corresponds to low values of dose rate, indicating a low present radioactivity, despite a large range of concentrations of RID's that are 
among the highest values measured in the sample collection (red area). These high concentrations of RID's are due to the record of high concentrations of radioelements that were present in the past and have been subsequently removed, leading to the present low dose rate. This situation corresponds to the so-called "temporary occurrence" in Fig. 4. The samples with the highest concentrations of defects are found in drill holes She 115 and She 115-2 of the Shea Creek area, but do not correspond to a same dominant clay mineral (Table 1). This past, vanished radioactivity was frequently observed up to $100 \mathrm{~m}$ distance from mineralization, as shown in Fig. $4 \mathrm{~b}$ and Table 1. The corresponding records of past radioactivity are significant and are not revealed by the present day radioactivity of sandstones which dose rate is among the lowest. The record of radioactivity of this sample is not thought to be an effect of the higher age of kaolinite because these samples also include illites and because the potential effect of age would be lower than the one observed in Fig. 4.

It is important to consider that the measurement of present day radioactivity would not distinguish between the red, yellow, and green families, in contrast to the EPR methodology.

Results obtained with EPR of clay minerals are similar to those obtained on quartz (Botis et al., 2006; Hu et al., 2008; Cerin et al., 2017), as only RID's in these minerals are able to record past radioactivity, provided that the combination of time and dose rate is high enough. From the study of U-poor laterites, we estimate that the order of magnitude of time necessary to produce measurable [RID] in clay minerals is around $1 \mathrm{Ma}$ for $\mathrm{ca} 1 \mathrm{ppm}$ of $\mathrm{U}$ and $10 \mathrm{ppm}$ Th (data not shown). The long exposure of clays to radioactivity in the Athabasca Basin (up to circa 1.7-1.5 Ga in the case of kaolinites) is thus favorable to the production of significant amounts of RID's. The analysis of RID's in quartz also provided clues for past circulation of $U$ in the Athabasca basin. Thus, Hu et al. (2008) demonstrated that drusy quartz from the McArthur River U deposit contained high levels of RID's without detectable present-day radioactivity, at distances reaching $400 \mathrm{~m}$ from the orebodies. This corresponds to a "temporary occurrence" as defined in our study. The methodology used on quartz and clay minerals is quite similar. However, quartz grains are usually much coarser than the alpha range in matter $(20 \mu \mathrm{m})$, whereas the whole clay grains can be irradiated by alpha particles if the radioelements are homogeneously disseminated in the clay matrix. Thus, the measurement of absorbed dose (joules per $\mathrm{kg}$ ) may be more difficult to assess in the case of quartz. This volumetric limitation may explain why no dosimetry with quartz from U-deposits has been published so far. In addition, the RID signal in clay minerals is more simple and the calculation of the corresponding concentration is relatively easy.

\subsection{Origin of temporary radioactivity recorded by the clay minerals}

The group of samples that have a low present-day dose rate but have significant concentrations of RID's in clay minerals (red area in Fig. 4), is suggestive of the presence of radioactivity in the past, and can potentially be explained by three main scenarios. In the first scenario, a past temporary flow of uranium-rich solutions has circulated without deposition of mineralization. High uranium concentrations of up to $600 \mathrm{ppm}$ have been measured in brines preserved in naturally occurring fluid inclusions in the mineral deposits from the Athabasca Basin (Richard et al., 2012, 2016). Circulation of such fluids would produce high concentrations of defects in relatively short times. Taking a low limiting case of $1 \mathrm{ppm} \mathrm{U}$ and $10 \mathrm{ppm}$ Th (see 3D plots section), which corresponds to about $3.7 \mathrm{ppm}$ of equivalent $\mathrm{U}$ in term of dose rate, the estimated minimum period of contact with such fluids would be circa 6000 years. This must have occurred soon in the deposit history, before the clogging of the porosity by secondary minerals and related decrease in permeability. This first scenario of circulation of U-rich fluids is also supported by the presence of continuous cathodoluminescence rims on detrital quartz (Botis et al., 2006; Cerin et al., 2017).

The second scenario is the temporary deposition of uranium-bearing minerals in the vicinity of clay minerals. The corresponding dose rate would be high because of the possible presence of higher amounts of uranium than in the first scenario. It would efficiently produce defects in clay minerals until the U-bearing minerals are dissolved and $\mathrm{U}$ is dispersed in the aqueous brine. This scenario suggests the existence of paleo-mineralized bodies with larger extensions than the present ones, most likely along structures where the porosity is relatively higher, allowing both deposition and later leaching of radioelements. However, the reasons for potential dissolution of the paleo-mineralized bodies in selected parts of the deposits with other parts remaining untouched are unclear.

The third scenario incorporates the accumulation of radon, a well known phenomenon in mining areas. Rn may accumulate in the sandstone after its release from the mineralized levels, and produce radiations arising from itself and related daughters, which would occur after the $\mathrm{U}$ mineralization event.

All possible explanations for the origin of the record of temporary occurrence of radioelements imply that porosity was favorable to their migration during circulation or after deposition. To be more specific on this issue, it is important to note that RID's are witnesses of cumulative doses, that is to say that they record a combination of time and dose rate (derived from concentrations of radioelements). A similar amount of RID's is expected to be induced by a short time with a high dose rate or a long time with low dose rate. Consequently, only constraints on time of events (accumulations or losses) and calibration of the RID signal in term of dose through artificial irradiations, as was performed before on other U-rich, clay-containing systems (Allard and Muller, 1998; Allard et al., 2007), will allow quantitative reconstruction of radioelement (mainly $U$ and daughters) transfers.

\subsection{Implications for the genesis of ore deposits}

The radioelements of interest in this study of Shea Creek U deposits are expected to be mostly uranium and daughter products, as Th is currently considered to be immobile, and potassium is hosted in illite. It appears that the main circulations of uranium revealed by the RID's in clay minerals mostly concern samples from the She 115 and She 115-2 drill holes. This shows that recording of $\mathrm{U}$ concentration event before subsequent leaching is limited to a restricted area with up to $100 \mathrm{~m}$ from the mineralization (Table 1; Fig. 4). In addition, late accumulation of uranium is observed up to about $50 \mathrm{~m}$ from the mineralization (Table 1).

The contrasts between present dose rates and [RID] is informative. In the case of temporary occurrence, recording of initial radioactivity is possible if the concentration of U (U-rich fluid or paleo-mineralization) was relatively strong or lasted a significantly long time with respect to the period since clay mineral crystallization. A similar rationale is valid for the accumulation of $\mathrm{U}$ : the accumulation must be relatively strong for the contrast of present dose rate and [RID] to be measurable.

The distance of temporary occurrence of radioelements (mostly $\mathrm{U}$ and daughters) obtained in this study show that important transfers of uranium occurred relatively far (up to $100 \mathrm{~m}$ ) from the main structures (fluid conduits) identified by the present mineralization. By providing evidence of past transfers of great amount of radioelements in the sandstone up to $100 \mathrm{~m}$ above the mineralized bodies, the data from our study are consistent with the conclusions of the $\mathrm{U}$, Th decay-chain isotopes study by Holk et al. (2003) and the fluid inclusion study by Richard et al. (2016). In addition, our results support the model by Hiatt and Kyser (2007) which consider that, in the Athabasca basin, the U-bearing fluid flows were essentially lateral and limited in vertical extent to the permeable basal formations of the Athabasca group sandstones.

The fact that past migrations of radioelements were detected up to $1000 \mathrm{~m}$ above the sandstone-basement unconformity in the central part of the Athabasca basin (Morichon et al., 2010b) indicate that the vertical distance of uranium migration recorded at Shea Creek cannot be 
generalized to all unconformity related uranium deposits of the Athabasca basin. Indeed, it seems to be highly dependent of the structural pattern (fault network) which controlled the direction as well as the duration of the past U-bearing fluid flows in each specific area. An extensive investigation of RID's concentration of clay minerals would be necessary at a larger regional scale to be more conclusive on this last point.

Finally, even if they do not totally preclude the uranium migration at a distance $>100 \mathrm{~m}$ above the sandstone basement unconformity of the Shea Creek area, the results of this study, in absence of additional data, e.g. on the geochemical background (see Section 4.6), indicate that it was not significant enough to be clearly recorded by RID's in clay minerals.

\subsection{Implications for uranium exploration}

The present results show that once the geosystem is characterized (type and age of clays, present dose rate, dosimetry), a simple additional measurement of [RID], compared to a reference, should inform about the possible proximity of uranium mineralized bodies. Our findings that mineralization bodies of the Shea Creek area can be detected from radiation defects of clay minerals up to $100 \mathrm{~m}$ above have a significant implication for uranium exploration. At the deposit scale, it could permit to discriminate the fertile zones from the barren ones and hence would help in the drill hole targeting of the exploration campaigns.

More particularly, evidence of temporary occurrences of concentrations of radioelements in the surroundings of known mineralized bodies may be relevant for better understand their genesis (particularly in terms of source and timing). The collected information about location of transfers concerns one spatial dimension, i.e. the vertical distance to the mineralization or unconformity. Recently, Cerin et al. (2017) examined the distribution of RID's in quartz in the Athabasca sandstone in two dimensions above basement-hosted mineralization near the edge of the basin. To make the information more useful for mining exploration, it will be relevant to gather spatial 3D data, i.e. coordinates of the samples together with the concentration of RID's, to picture paleo-occurrences of U-rich brines or paleo-mineralization. This will involve design of an appropriate sampling strategy, which was not the concern of the present study.

In addition to the spatial locations of the past radioactivity recorded by clay minerals, a better definition of the anomalies (past occurrence or late accumulation) can be achieved through calibration of the RID concentration in term of cumulative doses using artificial irradiations. Estimation of an equivalent uranium content (responsible for the RID content) offers the possibility to compare with present, actual uranium concentration and determine a mass balance of accumulation and loss since the formation of the clay minerals (Allard and Muller, 1998; Allard et al., 2007). In the same way, the geochemical background that was not investigated in detail in this study, may contain information about past transfers of radioelements because it corresponds to concentrations of RID's spread over 3 orders of magnitude. It potentially contains record of relatively lower concentration of $U$ in fluids in contact with clay minerals (or shorter contact with fluids) when compared to the conditions of the clear temporary occurrence defined in this study, that may concern vertical distances of several hundreds of meters.

\section{Conclusion}

The three-dimensional plots presented in this study are appropriate and suitable to clearly reveal different situations such as accumulations or losses of radioelements that occurred since the formation of clay minerals used as a record of radioactivity. Significant past transfers of uranium are identified over $100 \mathrm{~m}$ away from the present mineralization. This supports a recent model of long range lateral flow of U- bearing fluids limited to a few hundreds of meters above the mineralization in the permeable formation. Full reconstruction of migration episodes of radioelements will require time constraints and calibration of RID contents through artificial irradiation. The present study also represents a first step toward creating a spatial 3D picture of ancient radioelements pathways that will improve models of formation of claycontaining uranium geosystems or natural analogues of HLNWR, provided that sampling is appropriate.

\section{Acknowledgments}

M. Pagel is acknowledged for discussion about possible involvement of Rn in the record of radioactivity by clay minerals. K. Ansdell, Y. Pan and J. Mercadier are thanked for their positive and constructive reviews that improved the manuscript.

\section{Funding}

This work was supported by AREVA-Mines (Paris, France). AREVA Resources Canada is acknowledged for providing the samples.

\section{Appendix A. Supplementary data}

Supplementary data to this article can be found online at https:// doi.org/10.1016/j.gexplo.2018.02.003.

\section{References}

Aitken, M.J., 1985. Thermoluminescence dating. Studies in archaeological science. Academic Press, London (359 pp).

Alexandre, P., Kyser, T.K., Jirika, D., 2008. Critical geochemical and mineralogical factors for the formation of unconformity-related uranium deposits: comparison between barren and mineralized systems in the Athabasca Basin, Canada. Econ. Geol. 104, 413-435.

Alexandre, P., Kyser, T.K., Thomas, D., Polito, P., Marlat, J., 2009. Geochronology of unconformity-related uranium deposits in the Athabasca Basin, Saskatchewan, Canada and their integration in the evolution of the basin. Mineral. Deposita 44, 41-59.

Allard, T., Muller, J.P., 1998. Kaolinite as an in situ dosimeter for past radionuclide migration at the Earth's surface. Appl. Geochem. 13 (6), 751-765.

Allard, T., Ildefonse, P., Calas, G., 2007. Reconstruction of past uranium migration in a sedimentary deposit (Coutras, France): implications for a radwaste repository. Chem. Geol. 239, 50-63.

Allard, T., Balan, E., Calas, G., Fourdrin, C., Morichon, E., Sorieul, S., 2012. Radiationinduced defects in clay minerals: a review. Nucl. Instrum. Methods Phys. Res., Sect. B $277,112-120$.

Annesley, I.R., Madore, C., Portella, P., 2005. Geology and thermotectonic evolution of the western margin of the Trans-Hudson Orogen: evidence from the eastern subAthabasca basement, Saskatchewan. Can. J. Earth Sci. 42, 573-597.

Beaufort, D., Patrier, P., Laverret, E., Bruneton, P., Mondy, J., 2005. Clay alteration associated to Proterozoic unconformity-type uranium deposits in the East Alligator River uranium field, Northern Territory, Australia. Econ. Geol. 100 (3), 515-536.

Billault, V., Beaufort, D., Patrier, P., Petit, S., 2002. Crystal chemistry of Fe-sudoïtes from uranium deposits in the Athabasca basin (saskatchewan, Canada). Clay Clay Miner. 50, 70-81.

Botis, S., Pan, Y., Bonli, T., Xu, Y., Zhang, A., Nokhrin, S., 2006. Natural radiation-induced damage in quartz. II. Distribution and implications for uranium mineralization in the Athabasca Basin, Saskatchewan, Canada. Can. Mineral. 44, 1387-1402.

Calas, G., 1988. Electron paramagnetic resonance. In: Hawthorne, F.C. (Ed.), Spectroscopic Methods in Mineralogy and Geology. Reviews in Mineralogy. Mineralogical Society of America, Washington D.C, pp. 513-571.

Cerin, D., Götze, J., Pan, Y., 2017. Radiation-induced damage in quartz at the arrow uranium deposit, southwestern Athabasca basin, Saskatchewan. Can. Mineral. 55, $1-16$.

Chatagnon, B., 1986. La résonance paramagnétique électronique du centre E'1 dans le quartz. Aspect fondamental et intérêt en géologie et en prospection uranifère. [PhD Thesis]. Institut National Polytechnique de Lorraine, Nancy, France (316 pp).

Chi, G., Bosman, S., Card, C., 2013. Numerical modeling of fluid pressure regime in the Athabasca basin and implications for fluid flow models related to the unconformitytype uranium mineralization. J. Geochem. Explor. 125, 8-19.

Christensen, J.N., Evan Dresel, P., Conrad, M.E., Maher, K., Depaolo, D.J., 2004. Identifying the sources of subsurface contamination at the Hanford site in Washington using high-precision uranium isotopic measurements. Environ. Sci. Technol. 38, 3330-3337.

Clozel, B., Allard, T., Muller, J.P., 1994. Nature and stability of radiation-induced defects in natural kaolinites: new results and a reappraisal of published works. Clay Clay Miner. 42 (6), 657-666. 
Cui, T., Yang, J., Samson, I.M., 2012. Tectonic deformation and fluid flow: implications for the formation of unconformity-related uranium deposits. Econ. Geol. 107, 147-163.

Cumming, G.L., Krstic, D., 1992. The age of the unconformity-associated uranium mineralization in the Athabasca Basin, northern Saskatchawan. Can. J. Earth Sci. 29, 1623-1639.

Dahlkamp, F.J., 1993. Uranium ore Deposits. Springer-Verlag, Berlin (460 pp).

Derome, D., Cathelineau, M., Cuney, M., Fabre, C., Lhomme, T., Banks, D.A., 2005 Mixing of sodic and calcic brines and uranium deposition at McArthur River, Saskatchewan, Canada: a Raman and laser-induced breakdown spectroscopic study of fluid inclusions. Econ. Geol. 100, 1529-1545.

Ewing, R., Meldrum, A., Wang, L., Weber, W.J., Corrales, L.R., 2003. Radiation effects in zircon. In: Hanchar, J.M., Hoskin, P.W.O. (Eds.), Zircon. Reviews in mineralogy and Geochemistry. 53. pp. 387-425.

Fayek, M., Kyser, T.K., 1997. Characterization of multiple fluid-flow events and RareEarth-Element mobility associated with formation of unconformity-type uranium deposits in the Athabasca Basin, Saskatchewan. Can. Mineral. 35, 627-658.

Hiatt, E.E., Kyser, T.K., 2007. Sequence stratigraphy, hydrostratigraphy, and mineralizing fluid flow in the Proterozoic Manitou Falls Formation, eastern Athabasca Basin, Saskatchewan. In: Jefferson, C.W., Delaney, G. (Eds.), EXTECH IV: Geology and Uranium EXploration TECHnology of the Proterozoic Athabasca Basin, Saskatchewan and Alberta. 588. Geological Survey of Canada, pp. 1-22 Bulletin.

Hoeve, J., Quirt, D., 1984. Mineralization and Host Rock Alteration in Relation to Clay Mineral Diagenesis and Evolution of the Middle-Proterozoic, Athabasca Basin, Northern Saskatchewan, Canada. Saskatchewan Research Council SRC Technical Report 187, 187 pp.

Hoeve, J., Quirt, D., 1987. A stationary redox front as a critical factor in the formation of high grade, unconformity-type uranium ore in the Athabasca Basin, northern Saskatchewan, Canada. Bull. Mineral. 110, 151-171.

Hoeve, J., Sibbald, T.I.I., 1978. On the genesis of Rabbit Lake and other unconformitytype uranium deposits in northern Saskatchewan, Canada. Econ. Geol. Bull. Soc. Econ. Geol. 73, 1450-1473.

Hoeve, J., Sibbald, T.I.I., Ramaekers, P., Lewry, J.F., 1980. In: Ferguson, J., Goleby, A.B. (Eds.), Athabasca Basin Unconformity-type Uranium Deposits: A Special Class of Sandstone-type deposits? Uranium in the Pine Creek Geosyncline. International Atomic Energy Agency, Vienna, pp. 575-594.

Holk, G.J., Kyser, T.K., Chipley, D., Hiatt, E.E., Marlatt, J., 2003. Mobile Pb-isotopes in Proterozoic sedimentary basins as guides for exploration of uranium deposits. J. Geochem. Explor. 80, 297-320.

Hu, B., Pan, Y., Botis, S., Rogers, B., Kotzer, T., Yeo, G., 2008. Radiation-induced defects in drusy quartz, Athabasca basin, Canada: a new aid to exploration of uranium deposits. Econ. Geol. 103, 1571-1580.

Ikeya, M., 1993. New applications of electron spin resonance, Dating, Dosimetry and Microscopy, Singapore. World Scientific, New Jersey. London. Hong Kong (500 pp).

Jeanneret, P., Goncalves, P., Durand, C., Poujol, M., Trap, P., Marquer, D., Quirt, D., Ledru, P., 2016. Tectono-metamorphic evolution of the pre-Athabasca basement within the Wollaston-Mudjatik Transition Zone, Saskatchewan. Can. J. Earth Sci. 53, 231-259.

Jefferson, C.W., Delaney, G., 2007. EXTECH IV: Geology and Uranium EXploration TECHnology of the Proterozoic Athabasca basin, Saskatchewan, Canada. Econ. Geol. $102,1182-1183$.

Jefferson, C.W., Thomas, D.J., Gandhi, S.S., Ramaekers, P., Delaney, G., Brisbin, D., Cutts, C., Portella, P., Olson, R.A., 2007. Unconformity-associated uranium deposits of the Athabasca Basin, Saskatchewan and Alberta. In: EXTECH IV: Geology and Uranium EXploration TECHnology of the Proterozoïc Athabasca Basin, Saskatchewan and Alberta. 17. Geological Society, Special Publication, Saskatchewan, pp. 23-67.

Kister, P., Laverret, E., Quirt, D., Cuney, M., Patrier, P., Beaufort, D., Bruneton, P., 2006. Mineralogy and geochemistry of host rocks alterations associated with the Shea Creek unconformity-type uranium deposit (Saskatchewan, Canada). Part 2. Spatial distribution of the Athabasca group sandstone matrix minerals. Clay Clay Miner. 54, 295-313.

Kotzer, T.G., Kyser, T.K., 1995. Petrogenesis of the proterozoic Athabasca Basin, Northern Saskatchewan, Canada, and its relation to diagenesis, hydrothermal uranium mineralization and paleohydrogeology. Chem. Geol. 120, 45-89.

Kyser, K., Cuney, M., 2009. Unconformity-related uranium deposits. In: Cuney, M., Kyser, K. (Eds.), Recent and not-so-recent developments in uranium deposits and implications for exploration. 39. Mineralogical Association of Canada (MAC) and the Society for Geology Applied to Mineral Deposits (SGA) Short Course, Quebec, pp. 161-219.

Kyser, T.K., Hiatt, E.E., Renac, C., Durocher, K., Holk, G.J., Deckart, K., 2000. Diagenetic fluids in paleo- and meso-Proterozoic sedimentary basins and their implications for long protracted fluid histories. In: Kyser, K. (Ed.), Fluids and Basin Evolution. Mineralogical Association of Canada, Ottawa, pp. 225-262 (2000).

Laverret, E., Patrier, P., Beaufort, D., Kister, P., Quirt, D., Bruneton, P., Clauer, N., 2006. Mineralogy and geochemistry of host rocks alterations associated with the Shea Creek unconformity-type uranium deposit (West Athabasca Basin, Saskatchewan, Canada). Part 1. Spatial variation of illite properties. Clay Clay Miner. 54, 275-294.

Laverret, E., Clauer, N., Fallick, T., Patrier, P., Beaufort, D., Kister, P., Quirt, D., Bruneton, P., 2010. K-Ar dating and $\mathrm{d}^{18} \mathrm{O}-\mathrm{dD}$ tracing of illitization within and outside the Shea Creek uranium prospect, Athabasca Basin, Canada. Appl. Geochem. 25, 856-871.
Liewig, N., Clauer, N., Sommer, F., 1987. Rb-Sr and K-Ar dating of clay diagenesis in jurassic sandstones oil reservoirs, North Sea. Am. Assoc. Pet. Geol. Bull. 71, 1467-1474.

Maher, K., Bargar, J.R., Brown Jr., G.E., 2013. Environmental speciation of actinides. Inorg. Chem. 52, 3510-3532.

Mercadier, J., Cuney, M., Cathelineau, M., Lacorde, M., 2011. U redox fronts and kaolinisation in basement-hosted unconformity-related $U$ ores of the Athabasca basin (Canada): late U remobilization by meteoric fluids. Mineral. Deposita 46, 105-135.

Merroun, M.L., Selenska-Pobell, S., 2008. Bacterial interactions with uranium: an environmental perspective. J. Contam. Hydrol. 102, 285-295.

Morichon, E., Allard, T., Beaufort, D., Patrier, P., 2008. Evidence of native radiationinduced paramagnetic defects in natural illites from unconformity-type uranium deposits. Phys. Chem. Miner. 35, 339-346.

Morichon, E., Allard, T., Beaufort, D., Quirt, D., 2010a. An EPR study of native radiationinduced paramagnetic defects in sudoite (di-trioctahedral Al-Mg chlorite) from the alteration halo related to unconformity-type uranium deposits. Phys. Chem. Miner. 37, 145-152.

Morichon, E., Beaufort, D., Allard, T., Quirt, D., 2010b. Tracing past migrations of uranium in Paleo-Proterozoic basins: new insights from radiation-induced defects in clay minerals. Geology 38 (11), 983-986.

Pacquet, A., Weber, F., 1993. Pétrographie et minéralogie des halos d'altération autour du gisement de Cigar Lake et leurs relations avec les minéralisations. Can. J. Earth Sci. 30, 674-688.

Pagel, M., 1975. Détermination des conditions physico-chimiques de la silicification diagénétique des grès d'Athabasca (Canada) au moyen des inclusions fluides. CR Acad. Sci. Paris 280 (D), 2301-2304.

Pagel, M., Poty, B., Sheppard, S.M.F., 1980. Contributions to some Saskatchewan uranium deposits mainly from fluid inclusion and isotopic data. In: Ferguson, S., Goleby, A. (Eds.), Uranium in the Pine Creek Geosyncline. International Atomic Energy Agency, Vienna, Austria, pp. 639-654.

Quirt, D.H., 1995. Norm Calculation Procedure for Sandstone Clay Minerals. Saskatchewan Research Council (Publication No. R-1230-28-E-95, 14 p. plus appendices).

Quirt, D., 2001. Kaolinite and dickite in the Athabasca Sandstone, northern Saskatchewan, Canada. In: Publication 10400-16D01. Canada, Saskatchewan Research Council (14 pp).

Raffensperger, J.P., Garven, G., 1995. The formation of unconformity-type uranium ore deposits. 1. Coupled groundwater flow and heat transport modelling. Am. J. Sci. 295, 581-636.

Rainbird, R.H., Stern, R.A., Rayner, N., Jefferson, C.W., 2007. Age, provenance, and regional correlation of the Athabasca Group, Saskatchewan and Alberta, constrained by igneous and detrital zircon geochronology. In: Jefferson, C.W., Delaney, G. (Eds.), EXTECH IV: Geology and Uranium EXploration TECHnology of the Proterozoic Athabasca Basin, Saskatchewan and Alberta. 588. Geological Survey of Canada, pp. 193-210 Bulletin.

Ramaekers, P., Jefferson, C.W., Yeo, G.M., Collier, B., Long, D.G.F., Drever, D., McHardy, S., Jiricka, D., Cutts, C., Wheatley, K., Catuneanu, O., Bernier, S., Kupsch, B., Post, R.T., 2007. Revised geological map and stratigraphy of the Athabasca Group, Saskatchewan and Alberta. In: Jefferson, C.W., Delaney, G. (Eds.), EXTECH IV: Geology and Uranium EXploration TECHnology of the Proterozoïc Athabasca Basin, Saskatchewan and Alberta. 588. Geological Survey of Canada, pp. 155-191 Bulletin.

Richard, A., Pettke, T., Cathelineau, M., Boiron, M.C., Mercadier, J., Cuney, M., Derome, D., 2010. Brine rock interaction in the Athabasca basement (McArthur River U-deposit, Canada): consequences for fluid chemistry and uranium uptake. Terra Nova 22 (4), 303-308.

Richard, A., Banks, D.A., Mercadier, J., Boiron, M.C., Cuney, M., Cathelineau, M., 2011. An evaporated seawater origin for the ore-forming brines in unconformity-related uranium deposits (Athabasca Basin, Canada): $\mathrm{Cl} / \mathrm{Br}$ and $\delta^{37} \mathrm{Cl}$ analysis of fluid inclusions. Geochim. Cosmochim. Acta 75, 2792-2810.

Richard, A., Rozsypal, C., Mercadier, J., Banks, D.A., Cuney, M., Boiron, M.C., Cathelineau, M., 2012. Giant uranium deposits formed from exceptionally uraniumrich acidic brines. Nat. Geosci. 5, 142-146.

Richard, A., Cathelineau, M., Boiron, M.C., Mercadier, J., Banks, D.A., Cuney, M., 2016. Metal-rich fluid inclusions provide new insights into unconformity-related U deposits (Athabasca Basin and Basement, Canada). Mineral. Deposita 51, 249-270.

Riegler, T., Allard, T., Beaufort, D., Cantin, J.L., Von Bardeleben, H.J., 2016. The thermal stability of radiation-induced defects in illite. Phys. Chem. Miner. 43, 23-30.

Sheahan, C., Fayek, M., Quirt, D., Jefferson, C.W., 2016. A combined ingress-egress model for the Kianna unconformity-related uranium deposit, Shea Creek project, Athabasca basin, Canada. Econ. Geol. 111, 225-257.

Uri, F., 2012. Altération et minéralisation d'uranium à Shea Creek (ouest Athabasca, Saskatchewan, Canada): Vers un nouveau modèle génétique de gisement. [PhD Thesis]. University of Poitiers, France (338pp).

Wallis, R.H., Saracoglu, N., Brummer, J.J., Golightly, J.P., 1985. In: Sibbald, T.I., Petruk, W. (Eds.), Geology of the McClean uranium deposits: Geology of Uranium Deposits. 32. Canadian Institute of Mining and Metallurgy, pp. 101-131 Special.

Wilson, M.R., Kyser, T.K., 1987. Stable isotope geochemistry of alteration associated with the Key Lake uranium deposit. Econ. Geol. 82, 1450-1557. 